\title{
THE EFFECTIVITY TEST OF SHEEP RUMEN LIQUOR ENZYME ADDED TO PALM KERNEL MEAL ON ITS DECREASE OF CRUDE FIBER AND APPARENT DIGESTIBILITY COEFFICIENT FOR CATFISH Pangasius hypophthalmus DIET
}

\author{
Wahyu Pamungkas*), Dedi Jusadi**), and Nur Bambang Priyo Utomo* \\ ${ }^{*}$ Research Institut for Freshwater Fish Breeding and Aquaculture, Sukamandi \\ **) Departement of Aquaculture, Faculty of Fisheries and Marine Science, Bogor Agriculture University
}

(Received 27 May 2011; Accepted 28 September 2011)

\begin{abstract}
Two experiments were conducted to evaluate the hydrolysis of fiber content in palm kernel meal (PKM) by sheep rumen liquor enzyme and to know the apparent digestibility coefficient of hydrolyzed PKM for catfish Pangasius hypophthalmus. The first trial examined effectivity of sheep rumen liquor enzyme to decrease crude fiber content of PKM. The added volume of sheep rumen liquor enzyme was 0,20 , $40,60,80$, and $100 \mathrm{~mL} / \mathrm{kg}$ PKM and then it was incubated for 0,12 , and 24 hours. A factorial completely randomized experimental design consisted of 2 variables and triplicates were selected. The second trial was conducted to evaluate the apparent digestibility coefficients of hydrolized PKM for catfish. Apparent digestibility coefficients were determined using chromic oxide indicator added to both reference and test diets. The feed ingredients used in the trial were hydrolyzed PKM (PKMe) and unhydrolyzed PKM (PKM). Ten fishes with weighing around $20 \mathrm{~g}$ were used in the trial and held in $80 \mathrm{I}$ tanks. Feces were collected from three replicate groups of fish using a fecal collection column attached to fish rearing tank. PKM hydrolyzed with $100 \mathrm{~mL} / \mathrm{kg}$ and incubated for 24 hour showed the lowest crude fiber content $(6.99 \%$ among the treatments $(P<0.05)$. Apparent digestibility coefficient of hydrolyzed PKM was $57.57 \%$ compared with unhydrolyzed PKM 15.31\% Based on the evaluation in those parameters it was concluded that sheep rumen liquor enzyme added to PKM was effective to decrease crude fiber content of PKM and improve apparent digestibility coefficient of PKM for catfish.
\end{abstract}

KEYWORDS: apparent digestibility coefficient, catfish, crude fiber, palm kernel meal, sheep rumen liquor enzyme

\section{INTRODUCTION}

Palm kernel meal (PKM) which is a by- product of the palm kernel oil industry has been widely used as a feed ingredient for livestock. Proximate analysis showed that PKM has a pro- tein content between $13.6 \% 17.45 \%$ (Sundu et al., 2003; Orunmuyi et al., 2006; Hadadi et al., 2007), crude fat ranged between $17.1 \%-21.55 \%$ (Sundu et al., 2003; Hadadi et al., 2007) and crude fiber reached $18.33 \% 21.3 \%$ (Sundu et

\# Corresponding author. Research Institute for Freshwater Fish Breeding and Aquaculture, Jl. Raya Sukamandi No.2, Subang 41256, West Java, Indonesia. Tel.: +62 260520500

E-mail address: yhoe_pamungkas@yahoo.co.id 
al., 2003; Orunmuyi et al., 2006). The high crude fiber content of PKM due to requires to be reprocessed for using as fish feed raw material use as raw material for fish feed. The limitations of fish in digesting crude fiber. Crude fiber can be used maximum of $7 \%$ for fish diets and in the range of $3 \%$ to $6 \%$ crude fiber for catfish diets (Robinson et al., 2001).

One effort of processing of high-fiber feedstuffs that have been developed in the field of animal husbandry is the use of rumen liquor to decrease crude fiber content of feedstuffs. Sheep rumen liquor is a source of alternative materials that are cheap and easily used as a source of enzyme hidrolase (Moharrery \& Das, 2002). Rumen liquor contains of fiber degrading enzyme including $\alpha$ - amylase, galactosidase, hemisellulase, cellulase, and xylanase (Williams \& Withers, 1992). Development of utilization technology of rumen liquor in cattle feed inspires the aquaculturist to develop this technology in fish feed. One of the fishery commodities which are potential and have been developed by the community are catfish. Information digestibility of high fibrous feedstuffs in catfish has not been obtained yet. Base on the information above, the objective of the research was to evaluate the effectivity of sheep rumen liquor enzyme added to palm kernel meal on its decrease of crude fiber content and apparent digestibility coefficient for catfish, Pangasius hypophthalmus diet.

\section{MATERIALS AND METHODS}

The study was conducted in two trials that are the effectivity test of sheep rumen liquor enzyme to decrease the crude fiber content on palm kernel meal (PKM) and digestibility trials of PKM which have been hydrolyzed by rumen liquor enzymes for catfish diet.

\section{The Effectivity Test of Sheep Rumen Liquor Enzyme}

In the first trial, the enzyme was isolated from rumen liquor of sheep that was provided grass as a feed. The rumen liquor was centrifuged at 10,000 rpm for 20 minutes in $4^{\circ} \mathrm{C}$ conditions, then the supernatant was reacted with $60 \%$ ammonium sulfate using magnetic stirer and stored for 24 hours at $4^{\circ} \mathrm{C}$. Furthermore the rumen liquor was centrifuged and the formed sediment used as a source of enzyme (Budiansyah et al., 2010; Fitriliyani 2010). The obtained enzyme were tested for its activities including activities of cellulase (Ghosse, 1987), amylase and protease (Bergeyer \& Grassi, 1983), and lipase (Tietz and Friedreck referenced in Barlongan, 1990). The effectivity of enzymes in decreasing crude fiber of PKM was tested by adding the different volume of enzyme into the PKM, namely: $A(0 \mathrm{~mL} /$ $\mathrm{kg}), B(20 \mathrm{~mL} / \mathrm{kg}), \mathrm{C}(40 \mathrm{~mL} / \mathrm{kg}), \mathrm{D}(60 \mathrm{~mL} / \mathrm{kg}), \mathrm{E}$ $(80 \mathrm{~mL} / \mathrm{kg})$, and $\mathrm{F}(100 \mathrm{~mL} / \mathrm{kg}$ of PKM) with a incubation period of 0,12 , and 24 hours (Fitriliyani, 2010). A factorial completely randomized experimental design consisted of 2 variables and triplicates was selected. Crude fiber content and levels of Neutral Detergent Fiber (NDF), Acid Detergent Fiber (ADF), cellulose, hemisellulosa and lignin of PKM were observed before and after incubation (Takeuchi, 1988; Van Soest, 1991). Data were analyzed statistically using analysis of variance (ANOVA) and followed by Duncan test (Steel \& Torrie, 1993).

\section{Apparent Digestibility Test of PKM}

The feed ingredients used in the first trial were hydrolyzed PKM (PKMe) and unhydrolized PKM (PKM). The second trial was set up in completely randomized design with 3 treatments (100\%reference diet as control, 70\%reference diet and $30 \%$ PKMe as diet $\mathrm{A}, 70 \%$ reference diet and $30 \%$ PKM as diet B) and triplicates (Watanabe, 1988). Apparent digestibility coefficients were determined using chromic oxide indicator added to the reference diet and test diets. The feed composition and proximate composition of feed are presented in Table 1 and 2 .

Ten fishes with weighing around $20 \mathrm{~g}$ were used in the trial and held in $80 \mathrm{~L}$ tanks for 15 days. Water temperature and dissolved oxygen concentration were maintained at $30^{\circ} \mathrm{C}$ and 7,0 $\mathrm{mgL}^{-1}$ respectively. Fish were fed at satiation and feeding frequency was adjusted three times per day (Watanabe, 1988). Feces were collected from three replicate groups of fish using a fecal collection column attached to fish rearing tank. They were dried immediately at $110^{\circ} \mathrm{C}$ for $4-6$ hours. Fecal samples were analyzed for moisture, chromic oxide, protein, calcium, phosphorus, and energy. Apparent digestibility coefficient were calculated based on the procedure of Takeuchi (1988). At the end of the feeding trials. The feed consume, total digestibility, nutrient digestibility, ingredient digestibility and survival 
The effectivity test of sheep rumen liquor enzyme ... (Wahyu Pamungkas)

Table 1. Composition of reference and test diet (\%)

\begin{tabular}{lccc}
\hline Composition & $\begin{array}{c}\text { Reference Diet } \\
\text { (100\% commercial) }\end{array}$ & $\begin{array}{c}\text { Diet A } \\
\text { (30\% PKMe) }\end{array}$ & $\begin{array}{c}\text { Diet B } \\
\text { (30\% PKM) }\end{array}$ \\
\hline Comercial feed & 96.5 & 66.5 & 66.5 \\
PKMe & 0 & 30 & 0 \\
$\mathrm{PKM}$ & 0 & 0 & 30 \\
$\mathrm{CMC}$ & 3 & 3 & 3 \\
$\mathrm{Cr}_{2} \mathrm{O}_{3}$ & 0.5 & 0.5 & 0.5 \\
\hline \multicolumn{1}{c}{$\quad$ Total } & $\mathbf{1 0 0}$ & $\mathbf{1 0 0}$ & $\mathbf{1 0 0}$ \\
\hline
\end{tabular}

PKMe : Hydrolyzed PKM

PKM : Unhydrolized PKM

CMC : Carboxy Methyl Cellulosa

Table 2. Proximate composition of the reference and test diet (in dry weight)

\begin{tabular}{|c|c|c|c|}
\hline $\begin{array}{l}\text { Proximate } \\
\text { composition }\end{array}$ & $\begin{array}{c}\text { Reference diet } \\
\text { (100\%commercial feed) }\end{array}$ & $\begin{array}{c}\text { Diet A } \\
\text { (30\% PKMe) }\end{array}$ & $\begin{array}{c}\text { Diet B } \\
\text { (30\% PKM) }\end{array}$ \\
\hline Protein & 28.83 & 25.20 & 24.43 \\
\hline Fat & 7.12 & 6.97 & 7.72 \\
\hline Ash & 12.59 & 12.45 & 10.69 \\
\hline Crude Fiber & 4.66 & 5.36 & 8.36 \\
\hline NFE & 46.80 & 50.02 & 48.80 \\
\hline GE (ckal/ $100 \mathrm{~g}$ feed)* & 423.85 & 414.94 & 412.67 \\
\hline$C / P^{* *}$ & 14.703 & 16.466 & 16.892 \\
\hline
\end{tabular}

NFE : Nitrogen Free Extract

${ }^{*} \mathrm{GE}$ : Gross energy

${ }^{* *} \mathrm{C}$ : Energy; P: Protein

rate were measured. Data were analyzed statistically using analysis of variance (ANOVA) and followed by Duncan test (Steel \& Torrie, 1993).

\section{RESULTS AND DISCUSSION}

\section{Activity of Sheep Rumen Liquor Enzyme}

The result of measurement of cellulase, amylase, protease, and lipase activity are presented in Figure 1. The measurement result showed that activity of the cellulase enzyme was greater among others. The values of enzyme activity from the largest to lowest are cellulase $(0.31 \pm 0.015)$, amylase $(0.14 \pm 0.016)$, protease $(0.11 \pm 0.016)$ and lipase enzyme $(0.03 \pm 0.011)$ respectively.
Result of enzyme activity analysis showed that the cellulase enzyme activity of $0.31 \mathrm{IU} /$ $\mathrm{ml} /$ minute was higher than the activity of amylase, protease and lipase enzymes. The high activity of cellulase enzyme due to the sheep rumen liquor was taken from the sheep that was provided grass as feed. A grass has a high fiber content, so that in the rumen, the sheep requires more cellulase enzyme to digest grass. It causes cellulase enzyme activity obtained in this study is greater than the others. Moharrery \& Das (2002) stated that the activity of enzymes in the rumen liquor depended on the composition or treatment of food. Agarwal et al. (2002) reported that lambs weighing 23.5 $\mathrm{kg}$ that were fed milk until 8 weeks and passed with $50 \%$ concentrate and $50 \%$ grass until the age of 24 weeks found that the enzymes pre- 
Indonesian Aquaculture Journal Vol.6 No.2, 2011

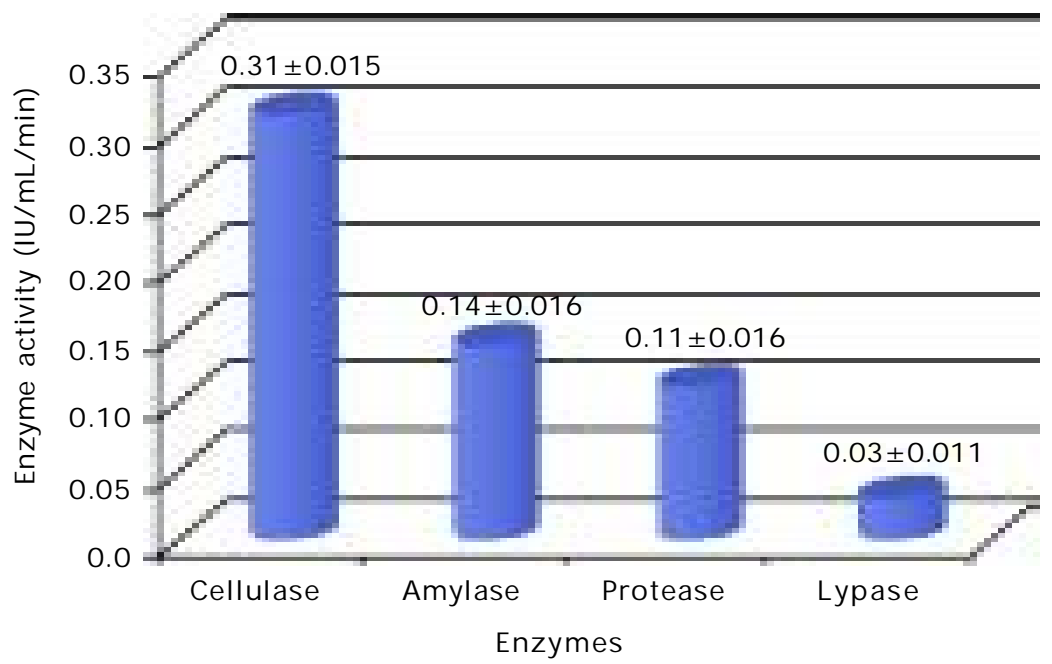

Figure 1. Activities of cellulase, amylase, protease and lypase enzymes in extracts of sheep rumen liquor

sented in rumen liquor were carboxymethyl celulase with 3.60 umol of enzyme activity of glucose per hour per $\mathrm{mL}$, alpha amylase 0.33 umol of glucose per minute per $\mathrm{mL}, 0.29 \mathrm{umol}$ xylanase xylosa per minute per $\mathrm{mL}$, beta- glucosidase 0.20 umol p- nitrophenol per minute per $\mathrm{mL}$, alpha-glucosidase $0008 \mathrm{~mol} \mathrm{p}$ nitrophenol per minute per $\mathrm{mL}, 0.05$ umol urease NHS- $\mathrm{N}$ per minute per $\mathrm{mL}$ and $452.7 \mathrm{ug}$ protease hydrolysis of protein per hour per $\mathrm{mL}$

\section{Crude Fiber Content and Levels of Glucose Dissolved}

The results of crude fiber content analysis and the decrease of crude fiber content in hydrolized PKM (PKMe) are presented in Table 3.

The result of analysis of dissolved glucose in PKM showed that dissolved glucose con- tent increase by adding volume of enzyme and the incubation period (Table 4).

The result of analysis of variance showed that the combination of volume of sheep rumen liquor added to PKM and incubation period give the significantly effect on its decrease of crude fiber content. The crude fiber content of unhydrolized PKM was higher than the others on the length of incubation time at 12 and $24 \mathrm{~h}$ but it is not significantly different at incubation period 0 hours. Crude fiber content in all treatments showed a significant decrease in 24 hours incubation period compared with 0 and 12 hours incubation period. The lowest crude fiber value of $6.69 \%$ was achieved by adding enzyme $100 \mathrm{~mL} / \mathrm{kg}$ for 24 hours incubation period. The value of $6.69 \%$ is significantly different from other treatments at 24 hour incubation period by adding enzymes $20,40,60$, and $80 \mathrm{~mL} / \mathrm{kg}$ of PKM which show

Table 3. Result of analysis of crude fiber content of hydrolized PKM

\begin{tabular}{ccccccc}
\hline $\begin{array}{c}\text { Incubation } \\
\text { period } \\
\text { (hours) }\end{array}$ & \multicolumn{5}{c}{ Volume of sheep rumen liquor enzyme/ kgPKM (mL) } \\
\cline { 2 - 7 } & $\mathbf{0}$ & $\mathbf{2 0}$ & $\mathbf{4 0}$ & $\mathbf{6 0}$ & $\mathbf{8 0}$ & $\mathbf{1 0 0}$ \\
\hline 0 & $17.54 \pm 0.18^{\mathrm{a}}$ & $17.63 \pm 0.20^{\mathrm{a}}$ & $17.22 \pm 0.20^{\mathrm{a}}$ & $16.71 \pm 0.21^{\mathrm{b}}$ & $17.06 \pm 0.16^{\mathrm{b}}$ & $16.06 \pm 0.16^{\mathrm{c}}$ \\
12 & $16.38 \pm 0.27^{\mathrm{d}}$ & $11.74 \pm 0.06^{\mathrm{e}}$ & $10.07 \pm 0.019^{\mathrm{f}}$ & $10.94 \pm 0.05^{\mathrm{g}}$ & $10.48 \pm 0.20^{\mathrm{h}}$ & $9.15 \pm 0.84^{\mathrm{i}}$ \\
24 & $15.55 \pm 0.27^{\mathrm{j}}$ & $10.92 \pm 0.45^{\mathrm{g}}$ & $9.40 \pm 0.23^{\mathrm{k}}$ & $8.86 \pm 0.45^{\mathrm{i}}$ & $8.38 \pm 0.36^{\mathrm{l}}$ & $6.69 \pm 0.30^{\mathrm{m}}$ \\
\hline
\end{tabular}

Different notation on the same column shows the significantly difference $(P<0.05)$ 
The effectivity test of sheep rumen liquor enzyme ... (Wahyu Pamungkas)

Table 4. Dissolved glucose content of hydrolized PKM (\%)

\begin{tabular}{ccc}
\hline \multirow{2}{*}{$\begin{array}{c}\text { Volume of sheep } \\
\text { Rumen liquor/ kg PKM ( } \mathbf{m L})\end{array}$} & \multicolumn{2}{c}{ Incubation period (hours) } \\
\cline { 2 - 3 } & $\mathbf{1 2}$ & $\mathbf{2 4}$ \\
\hline 0 & $0.040 \pm 0.001$ & $0.041 \pm 0.001$ \\
20 & $0.080 \pm 0.001$ & $0.169 \pm 0.003$ \\
40 & $0.122 \pm 0.003$ & $0.246 \pm 0.006$ \\
60 & $0.168 \pm 0.035$ & $0.333 \pm 0.064$ \\
80 & $0.218 \pm 0.008$ & $0.424 \pm 0.014$ \\
100 & $0.242 \pm 0.027$ & $0.469 \pm 0.049$ \\
\hline
\end{tabular}

crude fiber content values respectively $10.92 \% 9.40 \% 8.86 \%$ and $8.38 \%$ (Table 3 ).

The decrease of fiber content in hydrolyzed PKM is caused by cellulase enzyme activity that hydrolysis cellulose in PKM into simpler forms. The obtained result in the current study showed that the lowest crude fiber content of PKM $(6,69 \%)$ was achieved by adding $100 \mathrm{~mL} / \mathrm{kg}$ rumen liquor to PKM and incubation for 24 hours. While the highest increase of dissolved glucose content was $0.469 \%$ James et al. (2005) reported that the increase of enzyme concentration gave effect for substrate more than the increase of temperature during the hydrolysis process. Whereas Vijaya et al. (2002) explained that there was indication of increasing hydrolysis proses by increasing time of incubation.

The sheep rumen liquor enzyme was used to hydrolyze lamtoro leaves meal and the result obtained in the study showed that 100 $\mathrm{mL} / \mathrm{kg}$ rumen enzyme added on lamtoro meal and incubated for 24 hours decreased crude fiber content of $53.64 \%$ (Fitriliyani, 2010). The rumen liquor enzyme added on lamtor o meal broke down the difficult components to easily digested and can be utilized by the animal. She also reported that the sugar total content measured at 2 hours incubation produced a linear response curve while at 24 hour incubation showed quadratic response curve. Fitriliyani (2010) revealed that difference of this response caused by relationship between availability of the subtrate and incubation time. At 2 hours incubation enzyme will be hydrolyzing substrate whereas at 24 hours incubation enzyme has maximum to break down the available substrate. Result obtained in Alemawor research (2009) showed that there was a decrease of better nutrition quality by using multienzyme on feed raw material including increase of sugar total value and decrease of crude fiber, Neutral Detergent Fiber (NDF), Acid Detergent Fiber (ADF), cellulose and lignin.

\section{The content of Neutral Detergent Fiber (NDF), Acid Detergent Fiber (ADF), cellulose, hemicellulose and lignin}

Result of NDF, ADF, cellulose, hemicellulose, and lignin analysis on hydrolized PKM by sheep rumen liquor enzyme of $100 \mathrm{~mL} / \mathrm{kg}$ at 24 hours incubation period and unhydrolized PKM is presented in Table 5.

Result of fiber fraction analysis such as NDF, ADF, cellulose, hemicellulose, and lignin on PKM showed that the content of NDF, ADF, cellulose and lignin decreased on hydrolized PKM, whereas hemicellulose increased. The decrease of fiber fraction content on hydrolyzed PKM is 5.17\%NDF, $40.61 \%$ ADF, $36.28 \%$ cellulose, dan $43.61 \%$ lignin, while the increase of hemicellulose is $104.92 \%$ Alemawor (2009) reported that using of multienzyme added to feed raw materials increased nutritional quality such as increase glucose dissolved, decrease crude fiber, NDF, ADF, cellulose and lignin.

\section{Apparent Digestibility Test of PKM Hydrolyzed}

The observation of feed consumption, digestibility value (total, protein, $\mathrm{Ca}, \mathrm{P}$, energy, materials) and survival rate is presented in Table 6 . Analysis of variance showed that feed consumption and survival rate were not significantly different among the treatments $(P>0.05)$. This data indicate that the feed have a good 
Indonesian Aquaculture Journal Vol.6 No.2, 2011

Table 5. Composition of NDF, ADF, cellulose, lignin and hemisellulosa on PKM and PKMe

\begin{tabular}{lcc}
\hline \multicolumn{1}{c}{ Fiber fraction (\%) } & PKM & PKMe* $^{*}$ \\
\hline NDF & $75.10 \pm 0.015$ & $71.22 \pm 0.012$ \\
ADF & $56.81 \pm 0.061$ & $33.74 \pm 0.038$ \\
Cellulosa & $32.22 \pm 0.061$ & $20.53 \pm 0.012$ \\
Hemicellulosa & $18.29 \pm 0.026$ & $37.48 \pm 0.214$ \\
Lignin & $23.30 \pm 0.098$ & $13.14 \pm 0.083$ \\
\hline
\end{tabular}

* hydrolyzed PKM by sheep rumen liquor enzyme $100 \mathrm{~mL} / \mathrm{kg}$ at 24- hour incubation period

Table 6. Feed consumption, digestibility value (total, protein, energy, materials), DE and survival rate

\begin{tabular}{|c|c|c|c|}
\hline \multirow[b]{2}{*}{ Parameters } & \multicolumn{3}{|c|}{ Diet } \\
\hline & $\begin{array}{c}\text { Reference } \\
\text { (100\%commercial feed) }\end{array}$ & $\begin{array}{c}\text { A } \\
(30 \% \text { PKMe) }\end{array}$ & $\begin{array}{c}\text { B } \\
(30 \% \text { PKM) }\end{array}$ \\
\hline Feed consumption (g) & $134.14 \pm 2.30^{\mathrm{ns}}$ & $137.63 \pm 0.03^{\text {ns }}$ & $133.74 \pm 2.36^{n}$ \\
\hline \multicolumn{4}{|l|}{ Digestibility $(\%)$} \\
\hline Total & $75.23 \pm 0.49^{a}$ & $69.93 \pm 0.33^{b}$ & $57.26 \pm 0.35^{c}$ \\
\hline Protein & $91.63 \pm 0.40^{\mathrm{a}}$ & $87.86 \pm 0.57^{b}$ & $83.66 \pm 0.84^{c}$ \\
\hline Energy & $83.39 \pm 0.17^{a}$ & $72.72 \pm 0.14^{b}$ & $60.59 \pm 0.02^{c}$ \\
\hline Materials & - & $57.57 \pm 0.489^{a}$ & $15.31 \pm 0.217^{\mathrm{b}}$ \\
\hline DE (kcal/ 100gr) & $353.4 \pm 0.73^{a}$ & $300.5 \pm 0.16^{b}$ & $263.9 \pm 0.36^{c}$ \\
\hline SR $(\%$ & $100.00 \pm 0.00^{\mathrm{ns}}$ & $100.00 \pm 0.00^{\mathrm{ns}}$ & $100.00 \pm 0.00^{n s}$ \\
\hline
\end{tabular}

*) Different notation on the same row shows the significantly difference $(P<0.05)$

pallatability. Nutritional content, palatability, temperature, age, body weight and stomach capacity are factors that affect feed intake. The palatability of feed is determined by taste, smell and color of physical and chemical factors feed (Parakkasi, 1990).

Analysis of variance of digestibility coefficient showed significantly different among the treatments, where diet A with $30 \%$ PKMe has digestibility coefficient higher than diet $\mathrm{B}$ that used $30 \%$ PKM. This difference also occured on digestible energy (DE) value, where the treatments was significantly affect on DEvalue.

Digestibility value describes fish ability to digest feed and feed quality. Digestibility showed fraction of nutrien or feed energy that was digested and was not excreted into feces form (NRC, 1993). Result obtained in this study showed that digestibility value of feed with hydrolyzed PKM was higher than unhydrolyzed PKM. Mokoginta (1999) reported that the difference of feed and nutrient composition affected on protein and total digestibility. Base on the result of proximate analysis it was known that crude fiber content diet $B(8.36 \%)$ was higher than diet A (4.66\%). Halver (1989) reported that fish are less able to digest crude fiber because there are no fish gut microbes that can produce the enzyme cellulase. High content of crude fiber in fish feed will affect the digestibility and absorption of nutrients in the digestive system of fish. Protein digestibility value for all treatments in this current study showed more than $80 \%$ According to Ranjhan (1980), crude protein digestibility depends on protein content in feed. Low protein feed has low digestibility and vice versa. Protein digestibility depend on amount of protein in digestive tract (Tilman et al., 1991). The high protein content 
in feed will increase protein consume and further it will affect on feed digestibility value (Wahju J., 1997). Hertrampf \& Pascual (2000) reported that chicken was fed with PKM has energy digestibility, protein digestibility and crude fiber digestibility were $78.9 \% 59.8 \%$ and $24.4 \%$ respectively. Hertrampf \& Pascual (2000) recommended that using of PKM in feed ranged $5 \%$ to $10 \%$ for herbivorous and omnivorous, and 3\%to $8 \%$ for carnivorous.

Result of material digestibility measurement on hydrolyzed and unhydrolyzed PKM showed that material digestibility value of hydrolyzed PKM $(57.7 \%$ was higher than unhydrolyzed PKM (15.31\%). In described decreasing of hydrolyzed PKM digestibility for Pangsius hypopthalmus diet of $73.4 \%$ compared with unhydrolyzed PKM. The difference of feed digestibility value in this study also caused by the difference fiber fraction value of feed including NDF, ADF, cellulose and lignin. Van Soest et al. (1985) reported that NDF content strongly influence the ability of cattle to consume feed. Furthermore, it is said that the NDF content more than $56 \%$ reduced the level consumption of dry matter.

\section{CONCLUSION}

Based on the evaluation in those parameters it was concluded that sheep rumen liquor enzyme added to PKM was effective to decrease crude fiber content of PKM and improve apparent digestibility coefficient of PKM for catfish Pangasius hypopthalmus.

\section{REFERENCES}

Agarwal, N., Kamra, D.N., Chaundhary, L.C., Agarwal, I., Sahoo, A., \& Pathak, N.N. 2002. Microbial status and rumen enzyme profile of crossbred calves fed on different microbial feed additives. Letter in Applied Microbiology, 34: 329- 336.

Alemawor, Victoria, Dzogbefia, Emmanuel, O.K., Oddoye, \&James, H.O. 2009. Enzyme cocktail for enhancing poultry utilization of cocoa pod husk. Scientific Research and Essays, 4(6): 555- 559.

Budiansyah, A. 2010. Applications of cow rumen liquor as a source of enzymes, amino acids, minerals and vitamins at a local feed-based broiler diet ration. Dissertation. Bogor Institute of Agriculture, Bogor, Indonesia.
Barlongan, T.G. 1990. Studies on lipases of milkfish (Chanos chanos). Aquaculture, 89: 315- 325.

Bergmeyer, H.U. \& Grassi, M. 1983. Methods of enzymatic analysis. Vol. V: Enzymes 3: peptidases, proteinases and their inhibitors. VCH Verlagsgesellschaft $\mathrm{MBH}$, Weinheim.

Fitriliyani, I. 2010. Improving Nutritional of lamtoro leaf meal with addition of enzyme extracts of sheep rumen liquor for Tilapia (Oreochromis sp.) diet. Disertation. Bogor Institute for Aquaculture, Bogor, Indonesia.

Ghose. 1987. Measurement cellulose activities. Appl. Chem., 59(2): 252- 268.

Hadadi, A., Herry, Setyorini, Surahman, A., \& Ridwan, E. 2007. Utilization palm kernel waste for fish diet. Freshwater Aquaculture Journal, 4(1): 11- 18.

Halver, J.E. 1989. Fish Nutrition. Second Edition. Academy Press Inc, New York.

Hertrampf, J.W. \& Pascual, P.F. 2000. Handbook on Ingrediants for Aquaculture Feeds. Published by: Kluwer Academic Publisher, p. 119- 381.

James, I.T., Philip, B.G., \&Sheila, A.B. 2005. Optimization of conditions for the enzymatic hydrolysis of phytoestrogen conjugates in urine and plasma. Analytical Biochemistry, 341: 220- 229.

Moharrey, A. \& Das Tirta, K. 2002. Correlation between microbial enzyme activities in the rumen liquor of sheep under different treatments. Reprod. Nutr. Dev., 41: 513- 529.

Mokoginta, I., Takeuchi, T., Suprayudi, A.M., Wiramiharja, Y., \& Setiawati, M. 1999. Effect of different carbohydrate source on feed digestibility, feed efficiency and growth of gouramy (Osphronemus gouramy Lac.). Indonesian Aquatic and Fisheries Journal, $\mathrm{VI}(2):$ 13- 19.

National Research Council (NRC). 1993. Nutrient Requirements of Warm Water Fishes and Shellfishes. National Academy of Science Washington D.C., 102 pp.

Orunmuyi, M., Bawa, G.S., Adeyinka, F.D., Daudu, O.M., \&Adeyinka, I.A. 2006. Effects of Graded Levels of Palm-Kernel Cake on Performance of Grower Rabbits. Pakistan Journal of Nutrition, 5(1): 71- 74.

Parakkasi, A. 1990. IImu Nutrisi dan Makanan Ternak Monogastrik. Jakarta: UI- Press. 
Ranjhan, S.K. 1980. Animal Nutrition In The Trpoics. $3^{\text {rd }}$ Edition. Published M. L Scott and Associates: Ithaca. New York.

Robinson, E.H., Menghe, H.Li, \& Bruce, B.M. 2001. A practical guide to nutrition feeds, and feeding of Catfish. Bull. 1113. Mississippi Agricultural \& Forestry Experiment Station. Mississippi State University.

Steel, R.G.D. \& Torrie, T. 1993. Principles and Procedure of Statistic. McGraw Hill London.

Sundu, B. , Kumar, A., \& Dingle, J.G. 2003. Comparison of two commercial enzyme product of digestive beta mannan in broiler that consume palm kernel cake oil with a different level. Proceedings of the National Seminar on Sustainable Utilization of Biological resources, p. 19- 25.

Takeuchi, T. 1988. Laboratory Work-Chemical Evaluation of Dietary Nutrients, In Watanabe T. (ed): Fish Nutrition and Mariculture. Tokyo. Departement of Aquatic Biosciences Tokyo Univercity of Fisheries. JICA, p. 179- 233.

Tillman, A.D., Hartadi, H., Reksohadiprodjo, S., Prawirokusumo, S., \& Lebdosoekojo, S.
1991. Basic Animal Nutrition Science. Prints of the 5th. Yogyakarta: Gadjah Mada Univ Pr.

Van Soest, P.J., Robertson, J.B., \& Lewis, B.A. 1991. Methods for dietary fiber, neutral detergent fiber and non- starch polysaccharides in relation to animal nutrition. J. Dairy Sci., 74: 3,583- 3,597.

Vijaya, G.V., Gireesh, T., \& Gajanan, S.B. 2002. Effect of enzymatic hydrolysis of protein on growth of in milk. Journal of The Science of Food and Agriculture, 82: 493- 496.

Wahju, J. 1997. Ilmu Nutrisi Unggas. Cetakan ketiga. Gajah Mada University Press. Yogyakarta.

Watanabe, T. 1988. Fish Nutrition and Mariculture. Department of Aquatic Bioscience. Tokyo University of Fisheries. JICA, p. 7982.

Williams, A.G. \& Withers, S.E. 1992. Changes in the rumen microbial population and its activities during the refaunation period after the reintroduction of ciliate protozoa into the rumen of defaunated sheep. Canadian. J. Microbiology, 39: 61-69. 